\title{
DIFFERENCES IN EXCLUSIONARY DISCIPLINE CONSEQUENCE ASSIGNMENT BY THE ECONOMIC STATUS OF BLACK STUDENTS DETERMINED TO BE AT-RISK: A TEXAS, STATEWIDE ANALYSIS
}

\author{
Candace M. Pohl \\ Doctoral Student \\ Department of Educational Leadership \\ Sam Houston State University, USA \\ E-mail: stdcmr14@shsu.edu \\ Dr. John R. Slate \\ Professor \\ Department of Educational Leadership \\ Sam Houston State University, USA \\ E-mail: jrs051@shsu.edu
}

\begin{abstract}
This study was conducted to determine the degree to which economic status was related to Discipline Alternative Education Program placement assignments for Grades 8 and 9 Black boys and Black girls who were at-risk during the 2017-2018 school year. Inferential statistical analyses of Texas statewide data revealed the presence of statistically significant differences in the number of Discipline Alternative Education Program placement assignments by the economic status of Black boys and Black girls at both grade levels. Grades 8 and 9 Black boys and girls who were at-risk and who were economically disadvantaged were assigned to statistically significantly more of these exclusionary discipline consequences than their counterparts who were not economically disadvantaged. Grade 8 Black boys who were economically disadvantaged were assigned to these exclusionary discipline consequences two times more often than Grade 8 Black boys who were not economically disadvantaged. Grade 8 Black girls who were economically disadvantaged were assigned to these exclusionary discipline consequences two-thirds more often than Grade 8 Black girls who were not economically disadvantaged. Grade 9 Black boys and Black girls who were economically disadvantaged were assigned these exclusionary discipline consequences one-third more often than their non-economically disadvantaged peers. Implications and recommendations for future research were discussed.
\end{abstract}

Keywords: Discipline Alternative Education Program Placement, Economic Status, Discipline Consequences, Economically Disadvantaged, At-Risk, Exclusionary Discipline, Ethnicity/Race.

\section{INTRODUCTION}

Differences in Exclusionary Discipline Consequence Assignment by the Economic Status of Black Students Determined to be At-Risk: A Texas, Statewide Analysis

For students to achieve academic and social success, educational environments must be inclusive and equitable. Students of color and students in poverty have historically suffered in traditional educational environments that lack appropriate policies to support them in academics and their social-emotional development. In addition, many students of color and students who are 
economically disadvantaged may also be identified as at-risk of dropping out of high school (Rumberger, 2011). Although school systems continue to use various methods of discipline practice such as in-school suspension and expulsion, it is important to identify any disparities that might be present in discipline practices. Evidence of any inequities could then be used to establish and implement appropriate and equitable policies. In preparation for future academic and socialemotional student success, any inequity issues must be resolved.

Researchers (Bottiani, Bradshaw, \& Mendelson, 2016; Hilberth \& Slate, 2012; Hirschfield, 2018; Skiba, Arredondo, \& Williams, 2014; Skiba et al., 2011; Slate, Gray, \& Jones, 2016; Welsh \& Little, 2018) have demonstrated the presence of negative consequences that are associated with exclusionary discipline practices such as a lack of connectedness to school, a decrease in their sense of belonging, repeated delinquency, academic gaps, and dropping out of high school. In the State of Texas, 14 criteria exist to determine whether students are at-risk for dropping out of high school. These criteria range from low academic achievement and grade retention to pregnancy and discipline placements. Readers are directed to the Texas Education Code website (https://statutes.capitol.texas.gov/Docs/ED/htm/ED.29.htm\#29.081) for the complete list of criteria. Of note to readers are two identifiers that are not included in the Texas at-risk criteria: (a) students of color and (b) students who are economically disadvantaged.

The transition from middle school to high school can be a tumultuous experience and students who have a history of problematic behavior may find this transition to be especially difficult (McCallumore \& Sparapani, 2010; Neild, 2009; Queen, 2002). Black boys who are economically disadvantaged appear to have the most difficult time transitioning from middle school to high school, possibly due to a lack of support structures, low academic preparation, and behavioral problems (Queen, 2002). Neild (2009) described the transition from middle school to high school as an important predictor of successful high school graduation. For students who are already considered at-risk, a smooth transition becomes increasingly important as a successful ninth grade year can provide a strong foundation for the remainder of a student's high school years (McCallumore \& Sparapani, 2010; Neild, 2009; Queen, 2002).

A plethora of research investigations exist in which inequities have been documented in the assignment of discipline consequences to students of color (Bottiani et al., 2016; Bradshaw et al., 2010; Hilberth \& Slate, 2012; Skiba et al., 2011;Waller \& Waller, 2014). The continued use of exclusionary discipline consequences, specifically for students with special needs may negatively affect their educational opportunities. Of importance to the reader should be the large number of repeated Discipline Alternative Education Program placements to students who have previously been identified as being at-risk of dropping out of high school, are students of color, and/or are economically disadvantaged.

\section{STATEMENT OF THE PROBLEM}

School district leaders use Discipline Alternative Education Program placements, an exclusionary discipline consequence, for serious student misbehavior. According to the Texas Education Agency Public Education Information Management System discipline data for the 2018-2019 school year, the number of students who were assigned to a Discipline Alternative Education Program placement was 80,815 students. Of this more than 80,000 cases, 76,523 were members of ethnic/racial groups other than White; 63,256 were economically disadvantaged; and 62,877 students were determined to be atrisk. Despite the abundance of literature on the disproportionate disparities in the assignment of exclusionary discipline consequences to students of color and to students from poverty (Skiba et al., 2011; Slateet al., 2016; Waller \&Waller,2014), a shortage of research studies are available on exclusionary discipline consequences for students who are labeled as being at-risk. Even fewer published research articles could be located regarding the Discipline Alternative Education Program placements of students of color who were economically disadvantaged and students of color who were 
labeled as being at-risk. As such, the degree to which multiple student characteristics are related to disciplinary consequence assignments is largely unknown and merits investigation.

\section{PURPOSE OF THE STUDY}

Four purposes are present in this empirical, statewide investigation. The first purpose of this study was to determine the degree to which economic status was related to an assignment to a Discipline Alternative Education Program placement for Grade 8 Black boys who were at-risk. The second purpose of this study was to ascertain the extent to which economic status was related to an assignment to a Discipline Alternative Education program placement for Grade 8 Black girls who were at-risk. The third purpose of this study was to determine the degree to which economic status was related to an assignment to a Discipline Alternative Education Program placement for Grade 9 Black boys who were at-risk. The final purpose of this study was to ascertain the extent to which economic status was related to an assignment to a Discipline Alternative Education Program placement for Grade 9 Black girls who were at-risk.

\section{RESEARCH QUESTIONS}

The following research questions were addressed in this study: (a) What is the difference in assignment to a Disciplinary Alternative Education Program placement by the economic status of Grade 8 Black boys determined to be at-risk?;(b)What is the difference in assignment to a Disciplinary Alternative Education Program placement by the economic status of Grade 9 Black boys determined to be at-risk?; (c) What is the difference in assignment to a Disciplinary Alternative Education Program placement by the economic status of Grade 8 Black girls determined to be at-risk?; and (d)What is the difference in assignment to a Disciplinary Alternative Education Program placement by the economic status of Grade 9 Black girls determined to be at-risk?

\section{SIGNIFICANCE OF THE STUDY}

This study was conducted to add to the existing research literature available on inequities in discipline consequences. Numerous studies have been conducted on the inequities in discipline consequences (Hilberth \& Slate, 2012; Skiba et al., 2011; Waller \& Waller, 2014). Few researchers, however, have examined discipline consequences among students who are already determined to be at-risk. Stakeholders who could benefit from the information in this study include policymakers and education leaders such as school district administration and campus leaders.

\section{Research Design}

\section{METHOD}

A causal-comparative research design (Johnson \& Christensen, 2012) was used. In this study, one independent variable was present: economic status. The dependent variable was number of Discipline Alternative Education Program placements for Grade 8 and 9 Black boys and Black girls who were at-risk in the 2017-2018 school year. The advantage of using a causal-comparative research design was the ability to analyze archival, pre-existing data from the Texas Education Agency Public Education Information Management System.

\section{Participation and Instrumentation}

Participants in this study were Grades 8 and 9 Black boys and Black girls who were economically disadvantaged, at-risk, and had been assigned to a Discipline Alternative Education Program placement setting during the 2017-2018 school year. In Grade 8, 1,016 Black boys and 494 Black girls had been assigned a Discipline Alternative Education Program placement. With respect to Grade 9, 1,547 Black boys and 740 Black girls had been assigned a Discipline Alternative Education Program placement. The discipline data for this study were obtained through a Public Information 
Request to the Texas Education Agency's Public Education Information Management System. Data were then imported into the Statistical Package for Social Sciences software program for analysis on.

\section{RESULTS}

To ascertain whether economic status was related to Discipline Alternative Education Program placement assignments for Grade 8 and Grade 9 Black boys and girls who were at-risk, Pearson chisquare analyses were conducted. This statistical procedure was viewed as the optimal statistical procedure to use because frequency data were present for economic status and for disciplinary consequence assignments. As such, chi-squares are the statistical procedure of choice when both variables in each research question are categorical (Slate \& Rojas-LeBouef, 2011). In addition, with the large sample size, the available sample size per cell was more than five. Therefore, the assumptions for using a Pearson chi-square procedure were met.

For the first research question on the effect of economic status on Discipline Alternative Education Program placements for Grade 8 Black boys, the result was statistically significant, $\chi^{2}(1)$ $=28.413, p<.001$. The effect size for this finding, Cramer's V, was below small, .07 (Cohen, 1988). As revealed in Table 1, almost half as many Grade 8 Black boys who were economically disadvantaged were assigned to a Discipline Alternative Education Program placement than were Grade 8 Black boys who were not economically disadvantaged. Depicted in Figure 1 are the percentages of Discipline Alternative Education Program placement assignments of Grade 8 Black boys by their economic status.

Table 1. Descriptive Statistics Descriptive Statistics of Discipline Alternative Education Program Placements by the Economic Status of Grade 8 Black Boys

\begin{tabular}{|l|l|l|l|l|}
\hline & \multicolumn{2}{|l|}{ Assigned } & \multicolumn{2}{l|}{ Not Assigned } \\
\hline Economic Status & $n$ & Percent & $n$ & Percent \\
\hline Economically Disadvantaged & 1,016 & $18.2 \%$ & 4,557 & $81.8 \%$ \\
\hline Not Economically Disadvantaged & 127 & $11.5 \%$ & 927 & $88.5 \%$ \\
\hline
\end{tabular}

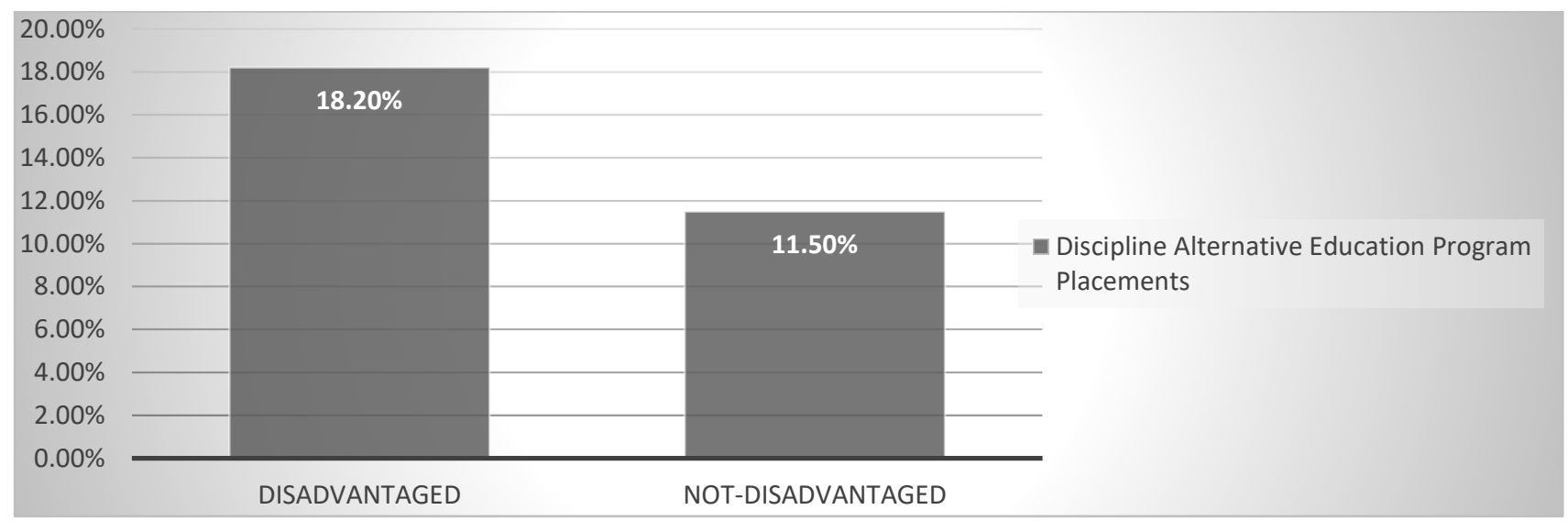

Figure 1. Percentage of Grade 8 Black boys and their Discipline Alternative Education Program placements by economic status.

For the second research question on the effect of economic status on Discipline Alternative Education Program placements for Grade 9 Black boys, the result was statistically significant, $\chi^{2}(1)$ $=19.326, p<.001$. The effect size for this finding, Cramer's V, was below small, .05 (Cohen, 1988). As delineated in Table 2 and depicted in Figure 2, more than one-third more Grade 9 Black boys who were economically disadvantaged were assigned to a Discipline Alternative Education Program placement than were Grade 9 Black boys who were not economically disadvantaged. 
Table 2. Descriptive Statistics of Discipline Alternative Education Program Placements by the Economic Status of Grade 9 Black Boys

\begin{tabular}{|l|l|l|l|l|}
\hline \multicolumn{2}{|l|}{ Assigned } & \multicolumn{2}{l|}{ Not Assigned } \\
\hline Economic Status & $n$ & Percent & $n$ & Percent \\
\hline Economically Disadvantaged & 1,547 & $24.5 \%$ & 4,757 & $75.5 \%$ \\
\hline Not Economically Disadvantaged & 253 & $18.9 \%$ & 1,084 & $81.1 \%$ \\
\hline
\end{tabular}

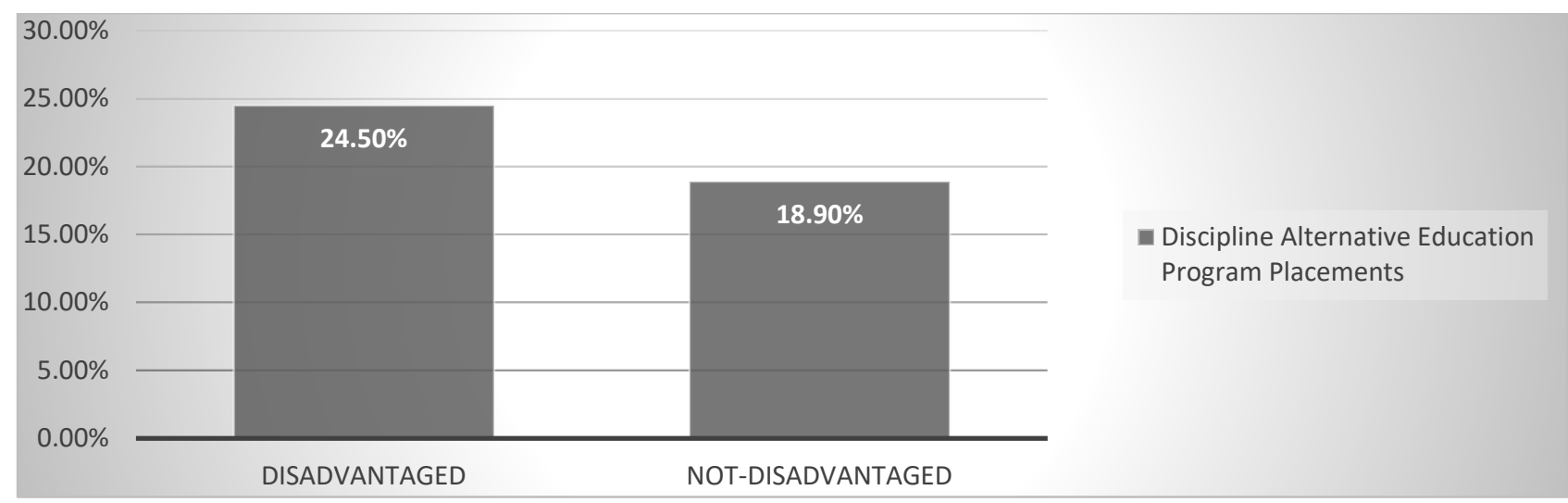

Figure 2. Percentage of Grade 9 Black boys and their Discipline Alternative Education Program placements by economic status.

For the third research question on the effect of economic status on Discipline Alternative Education Program placements for Grade 8 Black girls, a statistically significant difference was yielded, $\chi^{2}(1)=12.933, p<.001$. The effect size for this finding, Cramer's V, was below small, .06 (Cohen, 1988). As presented in Table 3, more than two-thirds as many Grade 8 Black girls who were economically disadvantaged were assigned to a Discipline Alternative Education Program placement than were Grade 8 Black girls who were not economically disadvantaged. Shown in Figure 3 are the percentages of Discipline Alternative Education Program placement assignments of Grade 8 Black girls by their economic status.

Table 3. Descriptive Statistics of Discipline Alternative Education Program Placements by the Economic Status of Grade 8 Black Girls

\begin{tabular}{|l|l|l|l|l|}
\hline & \multicolumn{2}{|l|}{ Assigned } & \multicolumn{2}{l|}{ Not Assigned } \\
\hline Economic Status & $n$ & Percent & $n$ & Percent \\
\hline Economically Disadvantaged & 494 & $15.1 \%$ & 2,786 & $84.9 \%$ \\
\hline Not Economically Disadvantaged & 45 & $9.0 \%$ & 454 & $91.0 \%$ \\
\hline
\end{tabular}

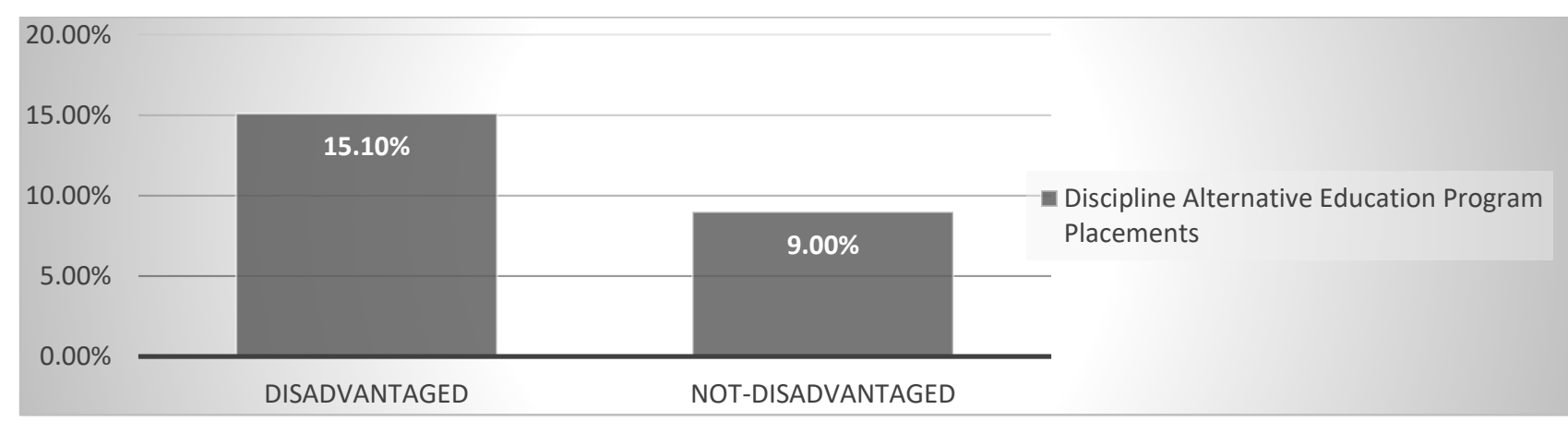

Figure 3. Percentage of Grade 8 Black girls and their Discipline Alternative Education Program placements by economic status. 
For the fourth research question on the effect of economic status on Discipline Alternative Education Program placements for Grade 9 Black girls, a statistically significant difference was revealed, $\chi^{2}(1)=7.830 p<.005$. The effect size for this finding, Cramer's V, was below small, .04 (Cohen, 1988). About a third more Grade 9 Black girls who were economically disadvantaged were assigned to a Discipline Alternative Education Program placement than were Grade 9 Black girls who were not economically disadvantaged. Table 4 contains the descriptive statistics for this analysis. Presented in Figure 4 are the percentages of Discipline Alternative Education Program placement assignments of Grade 9 Black girls by their economic status.

Table 4. Descriptive Statistics of Discipline Alternative Education Program Placements by the Economic Status of Grade 9 Black Girls

\begin{tabular}{|l|l|l|l|l|}
\hline & \multicolumn{2}{|l|}{ Assigned } & \multicolumn{2}{l|}{ Not Assigned } \\
\hline Economic Status & $n$ & Percent & $n$ & Percent \\
\hline Economically Disadvantaged & 740 & $18.8 \%$ & 3,206 & $81.2 \%$ \\
\hline Not Economically Disadvantaged & 101 & $14.3 \%$ & 603 & $85.7 \%$ \\
\hline
\end{tabular}

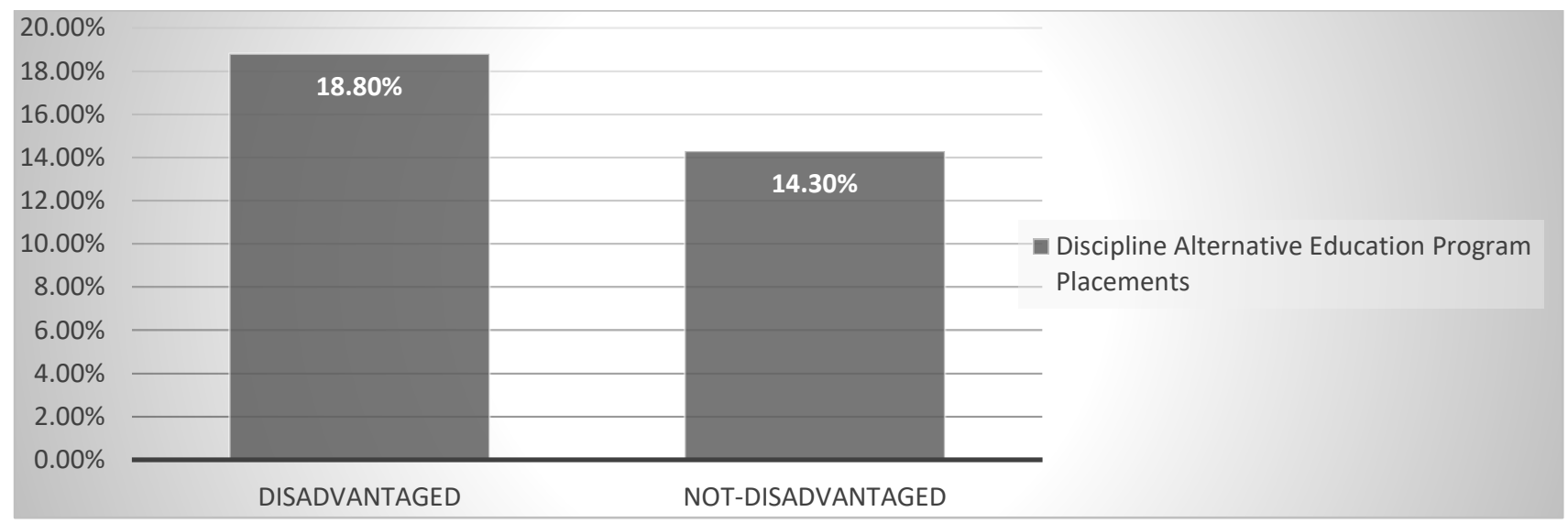

Figure 4. Percentage of Grade 9 Black girls and their Discipline Alternative Education Program placements by economic status.

\section{DISCUSSION}

In this study, the degree to which differences were present in Discipline Alternative Education Program placements by the economic status of Grades 8 and 9 Black boys and Black girls who were at-risk was addressed. For all four research questions, statistically significant differences were established in the number of Discipline Alternative Education Program placements of Grades 8 and 9 Black boys and Black girls who were at-risk by their economic status. Over 1,000 Grade 8 Black boys who were economically disadvantaged and who were at-risk were assigned to a Discipline Alternative Education Program placement compared to only 127 Grade 8 Black boys who were not economically disadvantaged and who were at-risk. This pattern was replicated for Grade 9 Black boys as well with 1,547 Grade 9 Black boys who were economically disadvantaged and at-risk who were assigned to a Discipline Alternative Education Program placement compared to only 253 Grade 9 Black boys who were not economically disadvantaged and who were at-risk.

With respect to Grade 8 Black girls who were economically disadvantaged and who were atrisk, almost 500were assigned to a Discipline Alternative Education Program placement compared to less than 50 Grade 8 Black girls who were not economically disadvantaged and who were at-risk. Similarly, 740 Grade 9 Black girls who were economically disadvantaged and who were at-risk were assigned to a Discipline Alternative Education Program placement compared to 101 Grade 9 Black girls who were not economically disadvantaged and who were at-risk. Readers should note, for both 
Black boys and girls, assignments to a Discipline Alternative Education Program increased from Grade 8 to Grade 9. This increase could be linked to the transition that occurs between middle school and high school. Clear evidence was obtained that the economic status of Grades 8 and 9 Black boys and girls was related to their assignment to this exclusionary discipline consequence.

Results from this study are congruent with the findings from previous research. Waller and Waller (2014) investigated the relationship of variables including race, at-risk status, and economic status, to placements in an alternative education setting. Students who were at-risk and Black students had a higher probability of receiving an alternative education placement than their peers. Hilberth and Slate (2012) analyzed disciplinary consequences assigned to Black and White students in Grades 6, 7 , and 8 and concluded that Black students received more in-school suspensions, out-of-school suspensions, and assignments to a Disciplinary Alternative Education Program placement statistically significantly more than White students. Similarly, Lopez and Slate (2020) investigated the relationship between ethnicity/race and Disciplinary Alternative Education Program placement assignments in Grades 6, 7, and 8 for boys in four school years. At all grade levels for each year, Black boys were assigned to Disciplinary Alternative Education Program placements at statistically significant higher rates than their peers.

\section{IMPLICATIONS FOR POLICY AND FOR PRACTICE}

From the findings of this study, several implications for policy and for practice are present. Policymakers are encouraged to evaluate discipline procedures for school districts that do not discriminate. Policymakers are also encouraged to provide discipline consequences that do not result in removing students from their instructional environment. Educational leaders should investigate their disciplinary procedures to determine the extent that this study is applicable to their school districts and campuses. Educational leaders should provide disciplinary consequences that are not exclusionary, instead consider a restorative approach.

\section{RECOMMENDATIONS FOR FUTURE RESEARCH}

Based upon the results of this investigation, several recommendations are possible for future research. As only Discipline Alternative Education Program placements were examined in this investigation, researchers are encouraged to extend this study to other exclusionary discipline consequences such as out-of-school suspensions. Researchers could also replicate this study with other grade levels, as only data on Grades 8 and 9 students were analyzed herein. Researchers could extend this study to include the ethnicity/race of other students. Finally, researchers could investigate how students who are atrisk may be more susceptible to exclusionary discipline practices than students who are not at-risk and determine the contribution of specific at-risk factors to higher rates of exclusionary discipline assignments.

\section{CONCLUSION}

In conclusion, the economic status of Grade 8 and 9 Black boys and Black girls who were at risk had a clear and demonstrable relationship to their assignment to a Discipline Alternative Education Program placement. Grade 8 Black boys who were economically disadvantaged and at-risk had almost twice as many Discipline Alternative Education Program placements when compared to Grade 8 Black boys who were not economically disadvantaged. Grade 8 Black girls who were economically disadvantaged and at-risk had over two-thirds more placements than Grade 8 Black girls who were not economically disadvantaged. In addition, Grade 9 Black boys and Black girls who were economically disadvantaged and at-risk had one-third more Discipline Alternative Education Program placements when compared to Black boys and Black girls who were not economically disadvantaged. Based on this Texas statewide analysis, it is obvious that the economic status of Grade 8 and 9 Black boys and Black girls who were at-risk is clearly related to their Discipline Alternative Education Program placements. 


\section{REFERENCES}

Bottiani, J. H., Bradshaw, C. P., \& Mendelson, T. (2016). A multilevel examination of racial disparities in high school discipline: Black and White adolescents' perceived equity, school belonging, and adjustment problems. Journal of Educational Psychology, 109(4), 532-545. https://doi.org/10.1037/edu0000155.supp

Bradshaw, C. P., Mitchell, M. M., O’Brennan, L. M., \& Leaf, P. J. (2010). Multilevel exploration of factors contributing to the overrepresentation of Black students in office disciplinary referrals. Journal of Educational Psychology, 102(2), 508-520. https://doi.org/10.1037/a0018450

Cohen, J. (1988). Statistical power analysis for the behavioral sciences (2nd ed.). Hillsdale, NJ: Lawrence Erlbaum.

Hilberth, M., \& Slate, J. R. (2012). Middle school Black and White student assignment to disciplinary consequences: A clear lack of equity. Education and Urban Society, 46(3), 312-328. https://doi.org/10.1177/0013124512446218

Hirschfield, P. J. (2018). The role of schools in sustaining juvenile justice system inequality. Future of Children, 28(1), 11-35. https://doi.org/10.1353/foc.2018.0001

Johnson, R. B., \& Christensen, L. (2012). Educational research: Quantitative, qualitative, and mixed approaches (4th ed.). Los Angeles, CA: Sage.

Lopez, E. L., \& Slate, J. R., (2020). Ethnic/racial disparities in Discipline Alternative Education Program placements for Texas Grades 6, 7, and 8 boys: A statewide, multiyear analysis. Advances in Educational Research and Evaluation, 1(1), 33-42. https://doi.org/10.25082/AERE.2020.01.006

McCallumore, K. M. \& Sparapani, E. F. (2010). The importance of the ninth grade on high school graduation rates and student success in high school. Education, 130(3), 447-456.

Neild, R. C. (2002). Falling off track during the transition to high school: What we know and what can be done. The Future of Children, 19(1), 53-76. https://doi.org/10.1353/foc.0.0020

Queen, J. A. (2002). Student transitions from middle to high school. New York, NY: Routledge. https://doi.org/10.4324/9781315852744

Rumberger, R. W. (2011). Dropping out. Cambridge, MA., Harvard University Press. https://doi.org/10.4159/harvard.9780674063167

Skiba, R. J., Arredondo, M. I., \& Williams, N. T. (2014). More than a metaphor: The contribution of exclusionary discipline to a school-to-prison pipeline. Equity \& Excellence in Education, 47(4), 546-564. https://doi.org/10.1080/10665684.2014.958965

Skiba, R. J., Horner, R. H., Chung, C. G, Rausch, M. K., May, S. L., \& Tobin, T. (2011). Race is not neutral: A national investigation of African American and Latino disproportionality in school $\begin{array}{llll}\text { discipline. School Psychology } & \text { Review, } & \text { 40(1), }\end{array}$ https://doi.org/10.1080/02796015.2011.12087730 
Slate, J. R., Gray, P. L., \& Jones, B. (2016). A clear lack of equity in disciplinary consequences for Black girls in Texas: A state-wide examination. The Journal of Negro Education, 85(3), 250260. https://doi.org/10.7709/jnegroeducation.85.3.0250

Slate, J. R., \& Rojas-LeBouef, A. (2011). Calculating basic statistical procedures in SPSS: A selfhelp and practical guide to preparing theses, dissertations, and manuscripts. Ypsilanti, MI: NCPEA Press.

Waller, S. K. \& Waller, L. R. (2014). Alternative discipline placements in Texas. The Global eLearning Journal, 3(1).

Welsh, R. O., \& Little, S. (2018). The school discipline dilemma: A comprehensive review of disparities and alternative approaches. Review of Educational Research, 88(5), 752-794. https://doi.org/10.3102/0034654318791582

\section{Copyrights}

Copyright for this article is retained by the author(s), with first publication rights granted to the journal. This is an open-access article distributed under the terms and conditions of the Creative Commons Attribution license (http://creativecommons.org/licenses/by/4.0) 